\title{
DENOUNCING CORRUPTION THROUGH VISUAL MEANS: CIVIL SOCIETY INITIATIVES IN POST-COMMUNIST ROMANIA
}

\author{
Alexandra OPREA, PhD candidate \\ Faculty of Political Sciences, University of Bucharest, Romania \\ École des Hautes Études en Sciences Sociales, Paris, France \\ oprea.alexandra@,fspub.unibuc.ro
}

\begin{abstract}
In the context of the anti-corruption social movements in post-communist Romania, what role do local civil society associations, and more specifically artivism play in the articulation of corruption as a public problem? This translates into the desire to overcome the idea of corruption as a heavy Balkan heritage that explains the existence of a contestation movement only through external pressure. Therefore, this study argues that through a specific form of artivism, Funky Citizens, a very active NGO on the anti-corruption stage, is an example of a modernizing agent in post-communist Romania. To do so, this socio-historical study uses concepts and perspectives borrowed from the theoretical field of pragmatic sociology instrumentalized for the pursuit of apprehending artistic activism mobilized in the anti-corruption fight. The argument put forward is that the specificity of the Romanian case can be grasped through visual means of expression of actors that promote this specific modernizing project. So, this research reveals a new attitude towards corruption, different from that present during the first 20 years after the revolution, which implies the need to investigate its references to the recent past. Finally, this contribution reflects on the usefulness of artivism as a new language to channel ideas, in the pursuit of contributing to the articulation of a certain type of public memory of communism.
\end{abstract}

Keywords Post-communism, Romania, Modernizing Agents, Anti-Corruption, Artivism.

\section{Introduction}

This article analyzes the visual strategies of a Romanian NGO, engaged in the local anticorruption civil society movement that emerged in the last decade. A lot has been written during the past years in an attempt to better apprehend the phenomenon of political corruption. Our approach has grown out of a basic dissatisfaction with two dominant approaches on the matter, the culturalist perspective on corruption and the legal one. The latter focuses on anti-corruption laws and policies as indicators of progress in this field while the former considers corruption a "cultural pathology inherited form a long history" (Engels et al., 2017, 5). 
So, if corruption is a "normalized" phenomenon in Romanian society, how can we explain that some people find it "abnormal"? A key to understanding lies in the dominant assumption that the condemnation of corruption would be an effect of the external pressure of the European Union in this direction. This is the thesis of external conditionality (Hein, 2015; Bratu, 2018; Văduva 2016). This research favors another approach, which is that of an endogenous transformation of the Romanian society, according to which the change does not take place exclusively under external pressure. On the contrary, we consider that local initiatives do exist and that they contribute to the crystallization of corruption as a problem on the public agenda.

By adopting a Durkheimian vision of corruption, which implies considering it a social phenomenon that presents certain regularity, and therefore certain "normalcy" (Durkheim, 1960, 65-72), we aim to grasp the local critique of the phenomenon of corruption. So, what are the operations through which local actors contribute to the process of denormalization of corruption? From a pragmatic point of view, to increase their visibility social actors need mediation. So, to apprehend this local color of anti-corruption, we analyze the work of a Romanian NGO, Funky Citizens, and two of their artistic initiatives to approach politics through visual representations, namely Mari Corupţi (Big Corrupti Figures) and Galeria trocului electoral (The Gallery of electoral barter). This article argues that through a specific form of artivism, Funky Citizens, a very active actor on the anti-corruption stage, is an example of a certain type of modernizing agent (Blitstein \& Lemieux, 2018) in post-communist Romania.

Artivism can be briefly defined as "a hybrid neologism that signifies work created by individuals who see an organic relationship between art and activism." (Sandoval \& Latorre, 2008:82). By evaluating art as a transformative experience, Suzanne Nossel describes these means of expression as a "valid tool for change" $(2016,104)$. Sharing this same belief, this sociohistorical study uses concepts and perspectives borrowed from the theoretical field of pragmatic sociology instrumentalized for the pursuit of apprehending artistic activism mobilized in the anticorruption fight. Therefore, this essay analyzes the visual means used by this association to publicly denounce corruption, by presenting it as an abnormal phenomenon. Funky Citizens is an openly committed apolitical association, that was never involved in the organization of street anticorruption movements in Bucharest. Thus, their invitation to action is channeled through alternative means of expression that focus more on education. The two projects mentioned above are relevant for the present study due to their modus operandi. This refers to collaborations with 
visual artists in order to instrumentalize new languages to channel the anti-corruption project, which is an original approach in the field. Further on, perceiving this social actor as a modernizing agent allows us to investigate its references to the recent past and its attempt to contribute to the articulation of a certain type of public memory, understood as a critical approach to memorial practices. This involves a certain dynamic of the artistic remembrance, always subject to reinterpretations and public affirmation.

The data used to answer our research question was collected during ethnographic observation at this association's headquarters but also on different sites of their projects, in Bucharest, between January 2019 and February 2020. Additionally, this field research allowed us to conduct interviews with the president of the association and some other members responsible for the projects. The empirical evidence was obtained, besides interviews with the NGO members, from the press articles around the launch of the two projects. Furthermore, two Romanian postrevolutionary publications were analyzed, the first Romanian political science journal, Sfera Politcii, and a newspaper, Revista 22. This was a publication associated with the first NGO officially recognized after the 1989 Revolution, Grupul de Dialog Social (The Social Dialog Group), a civil society association that aimed to examine the challenges confronting the new democracy. Despite their reduced popularity, the two publications offer a space for intellectual debate towards the main emerging social problems, which prompts us to claim the possibility of questioning the place of corruption within the framework of their publishing agenda. Both of them were available in paper format at that time and are digitalized today. The first part of the study uses this data as a support of our attempt to present the historicity of corruption in Romania.

The approach this article follows to address these issues can be structured in three main parts. The first part starts with an overview of the anti-corruption fight in post-communist Romania. This section exposes the endogenous buildup of corruption as a social problem, identifying three approaches of the phenomenon, presented chronologically. This historicity of corruption will allow, in the second section of this study, to illustrate why conceiving anticorruption fight as a conflict between different types of modernity allows for a better understanding of local specificities. The third part focuses on the analysis of two projects promoted by Funky Citizens through the use of artivism in the anti-corruption fight. 


\section{The local build-up of a public problem}

The 1990s were marked in ex-communist countries by the slow privatization of the state's property. This privatization is considered to be "the primary source of corruption" (Chiriac, 1997, 3) to which are added, "the subordinate economy, tax evasion, influence peddling and clientelism" (Chiriac, 1997, 3). The Romanian case makes no exception. During the first years after the Revolution, corruption was treated as a general state of affairs in post-communist Romania. We can, therefore, refer to it, as Ernesto Laclau would have said, as a floating signifier (Laclau, 2008).

A thorough examination of the media discourse during the 1990s in Romania points at a general attitude that makes corruption a defining trait of Romanian culture and history. Overall, two types of approaches to this phenomenon can be identified in the media. One can be summed up by this quotation: an "abstract notion, a state of affairs of a society, we have always had corruption, but we have never really had corrupt figures." (Chiriac, 1997, 3). Thus, corruption was seen as a second nature of parliamentarians, bankers, capitalists, politicians of the government party, ministers, and politicians of coalition parties. This phenomenon was therefore presented as a standard of normality for the transitional period, which was supposed to be quickly overpassed. So, the press this investigation analyzed regarded corruption as reminiscence of the communist era; often understood as nepotism, or another threat to democracy. However, this observation is not followed by an attempt to define the phenomenon, it always remains a reality with an axiomatic value. As a consequence, this first post-communist approach of corruption in the media can be conceptualized in terms of normalcy, since it describes corruption as the product of a burdensome heritage, specific to the Balkan region, that societies cannot escape from.

By the end of 1996, when general elections were organized, corruption became more and more visible in the media. The alternation in power, marked by the victory of the Democratic Convention ${ }^{1}$, brought forward a new president, Emil Constantinescu, who openly assumed the fight against corruption as the main objective of his mandate. From 1997 on, the subject received greater media coverage, which led to a more critical approach of the matter.

From this moment on, corruption was associated with people, more precisely politicians and businessmen. One discourse emphasized the existence of a so-called "republic of cousins"

\footnotetext{
1 A grand coalition of former so called "historical" parties, of center-right orientation.
} 
(Hurezeanu, 1996, 3), perpetuated after the Revolution through, the FSN ${ }^{2}$ governance first, followed by FDSN and PSD ${ }^{3}$, and commissioned by local barons. This formula refers to the communist clientele system, which, through the characters and structures inherited by the National Salvation Front, managed to find a place in the new democratic republic.

This brings us to the second approach of corruption, which comes up against the normalizing one. It's what we call the fatalistic attitude towards corruption, a political and social phenomenon that Romania cannot escape from. Even though this subject gradually finds its place on the public agenda, the way of conceiving and explaining the existence of this phenomenon remains always linked to culturalism. Criticism of corrupt politicians does not, therefore, go hand in hand with an attempt to define and understand the phenomenon. On the contrary, the fatalistic attitude is adopted to explain the lack of solutions in this area of anti-corruption.

Starting from the 2000s, a change in approaching the matter has been noticed. Thus, corruption gradually acquired momentum to cause scandal and to mobilize the masses. In 2004, Traian Băsescu won the presidential elections, on a program focused on the anti-corruption theme. On October the $20^{\text {th }}, 2015$, the death of a police officer, member of Gabriel Oprea's escort, the minister of internal affairs at the time, provoked the emergence of a contestation movement, denouncing the existence of the minister's clandestine agenda and the use of his escort for private interests. "Say no to the abuse of power" was the motto that followed this scandal, used in public sphere to denounce this type of corruption.

Then, on October the $30^{\text {th }}, 2015$, the fire that started at a nightclub, Colectiv, resulting in 64 victims and 147 injured, led to a series of public protests with one common goal: fighting corruption. Under the catchy slogan "Corruption kills", that shows a new attitude toward this phenomenon, civil society denounced politicians who had been found guilty of endangering the lives of citizens by authorizing the operation of a nightclub that did not meet safety standards. The following big street protests ultimately led to the overthrow of the social-democratic government of Victor Ponta. This crescendo culminated in 2017, when Romania witnessed the biggest street

\footnotetext{
${ }^{2}$ National Salvation Front, the party of President Ion Iliescu, who is in power until the organization of the first free elections, associated by opponents with the former communist nomenklatura.

${ }^{3}$ In 1992, there was a split within the FSN, following which a faction of those members how were close to Ion Iliescu formed a new political party, the National Salvation Democratic Front (FDSN). This political formation changed its name again in 1993 to become the Party of Social Democracy in Romania (PDSR) and thus to assume more openly the social-democratic character. It was the forerunner of the current Social Democratic Party.
} 
protests since the 1989 Revolution. Hundreds of thousands of Romanians took to the streets to protest the decrees of the social democratic government that were adopted clandestinely in January 2017, during nighttime, to dismantle the laws of justice. In this case, the main claims of manifestations concerned the fight against corrupt political elites, and more specifically a reaction to the government's decisions to slow down the fight against corruption. ${ }^{4}$ These protests are considered to be very unusual, in the context of a country where this type of phenomenon has been marginal until very recently (Iancu, 2018, 392).

Scientific studies that consider culture an irreducible element of the development of a certain human behavior (Rozin, 2006, 158) arrive at fairly fatalistic conclusions trying to come up with explanations for the strong civic engagement of recent years in the Romanian anti-corruption fight. This is the case of Michael Hein, among others, who, in 2015, noted how the progress made in recent years in anti-corruption had been only reflected in standards, but not in practices. According to his main hypothesis,

"the configuration of formal rules and the dynamics of formal institutions significantly influences the consequences of anti-corruption efforts, but not (or not materially) the extent of corruption. The latter can primarily be explained by informal factors such as political culture, persistent patrimonial networks, historical legacies, poor economic capacities and high economic inequality." $(2015,772)$

While corruption appears to be systemic throughout society, it is also denounced by certain social categories of the same group. Therefore, the question arises if the anti-corruption social movements are only caused by the existence of an external standard, imposed after the accession to the European Union, or is it rather a criticism endogenous to society? These are some of the challenges that we have in mind in our attempt to see if the virulent anti-corruption criticism of the past few years has been generated only under external pressure, or there has been a local discourse, or maybe both.

\footnotetext{
${ }^{4}$ Key events impactful for the anti-corruption movement were identified by Jens Ivo Engels, Silvia Marton and Frédéric Monier, in "Des politiques blancscommeneige", La Vie des Idees, 2017, p. 6
} 


\section{The cut down of the social space}

After the 1989 Revolutions, the main cleavage that dominated the political scene in all the emergent eastern democracies did not fit the well-known "right-left" dichotomy. As Anthony Todorov points out, during the 1990s, the main cleavage in these countries revolved around such notions as neo-communist and anti-communist $(2019,35)$. This founding cleavage of the new political regime plays the role of a substitute for any other ideological positioning. Thus, according to Cristian Preda, this cleavage was defined as opposition in terms of legitimacy, in the context in which the parties that emerged after 1989 claimed, on one hand the Revolutionary heritage, and on the other hand the tradition or the Romanian historical legacy $(2005,71-74)$. An ethnographic study conducted in the early 2000s came to similar conclusions. More precisely, it claims that neocommunism versus anti-communism cleavage remains a central benchmark around which new forms of conceiving Romanian political identities are articulated (Zirelli, 2013, 212-229).

This same phenomenon can be observed in the press of the 1990s. From this point of view, in order to sum up, considering the initial complexity of the Romanian post-revolutionary political scene, the opinion formulated by Alexandru Radu seems quite relevant and revealing. He considers legitimate to speak of "a Romanian specificity of the communist-anticommunist dichotomy, a dichotomy that did not exist before 1989, and then manifested itself through the opposition between the neo-communist revolutionaries of the FSN and the historical parties" (2010).

This founding cleavage of the post-revolutionary democratic political life, which revolved around ties to the communist political regime, was transformed, in the absence of any right-left ideological crystallization, into a new type of rhetoric. As scientific research has shown, this cleavage slowly shifted, by the end of the 1990s, only to make room for a new one that gravitated around the theme of corruption.

"Despite the reformist drive, the new anti-corruption discourse did not entail visible outcomes, but produced rather a division within the political system between the 'conservatives' (those skeptical of the political neutrality of such policies) vs. the 'reformists', now rebranded as exponents of 'Europeanism"' (Iancu, 2018, 404).

This article leaves behind the approach that makes the fight against corruption a theme that, from the end of the 1990s, opposed "conservatives" to "reformists". Instead, a socio-historical 
approach of this matter makes it possible to conceive corruption as a source of conflict, which leads to an extreme simplification of the social space, by opposing two camps, two social groups, therefore two types of modernity.

By using the term modernity, we do not adhere to the most developed paradigms that have historically instrumentalized the word. Thus, this concept is not attached to the evolutionist paradigm, neither to the post-colonial visions on modernity. In contrast, it is used according to a relatively new research program that emerged more recently, by the end of 2010, and whose main characteristics were presented in a special number of the scientific magazine Politix (Blistein \& Lemieux, 2018). In this sense, modernity doesn't have any ontological attribute, but a pure methodological utility. Therefore, it is an instrument that helps social scientists in their research.

Briefly, the idea of modernity is understood here as a collective idealization of what a society should be (Blitstein, 2018). As a consequence, the task of the researcher is to identify the conflicts that occur between these different ideals which are closely linked to the social groups that produce and promote them (Lemieux, 2018, 127). This involves the existence in a given society of modernizing agents, who can be any type of agent who has developed the consciousness that a historical rupture has taken place and therefore wants a social transformation to occur, according to a determined project of society (Blistein \& Lemieux, 2018, 20). Their account is worth quoting at length.

"The modernizing agents have in common the development of an awareness of living in a society which has experienced a break with its past and which now aims to reach a certain ideal of society. Such awareness based on the idea of a "project" of society, as such resolutely oriented towards the future, is radically different from the mentality specific to societies in which normative references are anchored in a mythical past and where political obsession, far from being a change, is its limitation and sometimes even its denial" (Blitstein \& Lemieux, 2018, 19)

Nevertheless, imagining the future supposes a certain stance towards the past. For that reason, in analyzing different types of modernizing agents we find it important to investigate their approach to public memory. Johann Michel argues that "memories can be the subject of controversy, of disputes in public arenas which can refer to grammars (to tell, to argue, to interpret ...) which are instantiated in a situation to justify one memory order rather than another" (Michel, 
$2015,2)$. Thus, we adhere to this opinion that uses the concept of public memory to design a more reflexive approach of the social actors to the past. This means that remembrance practices are always subject to change and reinterpretation (Oprea, 2019).

Opposing conservatives to progressives is a very common attitude in the political field. However, according to Cyril Lemieux, this is a limiting approach berceuse it denies to one social group the ambition to define their vision on the future, hence, to embody a modernizing ideal. $(2018,134)$. This change of view produces, in the Romanian case, new categories. The first type of modernity that can be identified is what we call post-revolutionary modernity produced by the FSN, that considers corruption an external emanation, a false problem imposed by the European Union standard. Thus, the future of Romanian democracy would not be influenced by the presence or absence of this political phenomenon. The second project was the anti-communist modernity that slowly shifted into the anti-corruption one. For these modernizing agents, corruption, as communism, is a major threat to democracy and to social justice. To promote their values, they take the European standard as a source of legitimacy. As mentioned earlier, this study argues that through a specific form of artivism, Funky Citizens is an exponent of this anti-corruption modernizing agent.

\section{Artivism as a form of political art}

In this context, artivism practices that engage with anti-corruption discourses in Romania can be thought of in relation to the modernizing agent perspective. According to Sarah Mekdjian, "artivism brings together diverse creations, whether they take the form of verbal or visual signs, graffiti, maps, installations or performances, that all have social change as their political purpose." $(2018,1)$.

If political art is art that addresses political subjects, in striking contrast,

"“activist art' also explores political topics but is distinguished from political art in its greater concern with the politics involved in both the creation and the reception of the art. Activist artists actively seek public participation in both areas, and generally do not make a sharp distinction between the process or creating work and the product. Activist art is, therefore, political in two senses, while political art is political only in its subject matter." (Mullin, 2003) 
To put it short, as Lucy Lippard observes in her Trojan Horses: Activist Art and Power,“ 'Political' art tends to be socially concerned and 'activist' art tends to be socially involved - not a value judgment so much as a personal choice. The former's work is commentary or analysis, while the latter's artworks within its context, with its audience" $(1984,6)$. This perspective is useful to this study as it emphasizes the fundamental role played by action in this relationship, where art and activism empower each other. For Lippard, art has a "pragmatic nature" and therefore artivism is not necessarily a means of expression for professional artists, but a means of expression and creation for all those who have an ideal for the future of their society.

A joint research project of the University of Madrid and the University of NottinghamTrent that explored the educational potential of artivism concluded that this form of political participation is a "new language", or a "way of channeling ideas" (Aladro-Vico et al, 2018, 12).

"After several weeks working with artivists and young university students, artivism turned out to be a fundamental educational form, in addition to a language and way of communicating and expressing autonomy, dissidence, and opposition" (14)

Selmin Kara \& Camilla Møhring Reestorff, referring to documentary artivism, explain that this form of activism "adapts 'symbols or mechanisms created by the media' to gain a voice and visibility in the public sphere." $(2015,4)$. When it comes to the audience, engaging with it in open dialogue is an important characteristic that artivism has in common with all other types of activism, and that overcomes aesthetic values.

Mindi Rhoades (2015) underlines reflective qualities of artivism, by defining it as "an art based critical civic praxis". More specifically, "building a community of care around common concerns" (321), building connections and critical consciousness of the individual power of agency, are the vital components of artivism that will also guide this present study.

\section{The artivist element in the anti-corruption fight}

Having seen how artivist practices can engage with political themes, this section turns to the case study, a very active association on the Romanian anti-corruption scene, Funky Citizens. This NGO was founded in 2012 by its current president - a former member of Transparency International. She laid the foundations of the NGO with the financial support of the Embassy of the United States of America, in Bucharest, after winning a competition for citizen anti-corruption 
initiatives and institutional transparency. So, this organization has the ambition to be a "grassrooted" ${ }^{5}$ organization that is active in the field of transparency (Open Government, Open Data), anti-corruption and justice. Their target audience is mainly made of:

"young people, which means less than 45 years old, very active, coming from the urban environment, educated, hipsters, young professionals, middle class, but not from an economic point of view, or not only from an economic point of view but rather from their interests' point of view. It means people who are not worried about tomorrow, and because of that, we think they should be interested in public affairs, in the well-being of society. We often wonder if our approach is not too elitist but, after all, our resources are too limited... Our philosophy is therefore to invest in these people to whom we come more easily, so that they become our partners. Then, once they are convinced, and well equipped, they can pass the information on to their families, friends, relatives, in communities that otherwise would have been inaccessible to us." 6

During the past two years an opening up to a younger public can be noticed, mainly students, through civic education programs. These are high school students, under the age of 18 , but also students under the age of 22-23. More precisely, this organization focuses mainly on civic education and development of critical thinking of the target public described above. Thus, their main objective is to create a network of individuals that can, later on, become their contacts and partners. In the beginning, their actions focused on the public in Bucharest, mainly because of a lack of resources, but in 2019 they tried to spread their network. Caravana Civică (The Civic Caravan) is a project that allowed this NGO to travel to 21 Romanian smaller towns. While their public remains urban, this expansion allowed them to grasp different types of local themes and to articulate their national ones in other cities than Bucharest.

To help make this discussion more concrete, we will focus on two examples of public visual articulation of the anti-corruption discourse. Mari Corupti (Big Corrupt Figures) is Funky Citizens' initiative to transform all notorious political figures investigated for corruption by the National Anticorruption Directorate (DNA) into playing cards. In addition, this project offers an educational platform that explains, in an accessible way, what corruption is (from a legal point of

\footnotetext{
${ }^{5}$ Interview with the association's president - October 27, 2019.

${ }^{6}$ Idem.
} 
view). By keeping track of big corruption scandals, it also aims to offer an image of the impact of this phenomenon in Romania, contributing to the endogenous history of anticorruption ${ }^{7}$. Hence, they created the website - a database - that came out of the need to keep track of all mandatory sentences given by the anti-corruption Prosecutor's office (DNA) ${ }^{8}$. Moreover, in collaboration with Wanda Hutira, a graphic artist, they designed The Big corrupt figures kit, a series of collectible cards with an album (in the form of a metaphorical prison) that were commercialized together with the DoR (Decât o Revistă) ${ }^{9}$ magazine in the pilot phase. Afterwards, the kit remained available for purchase on the website. The official release of this project took place at an Urban Art Festival in Bucharest, called Street Delivery, between the $12^{\text {th }}$ and the $14^{\text {th }}$ of June 2015.

Figure 1: The Sticker's Structure

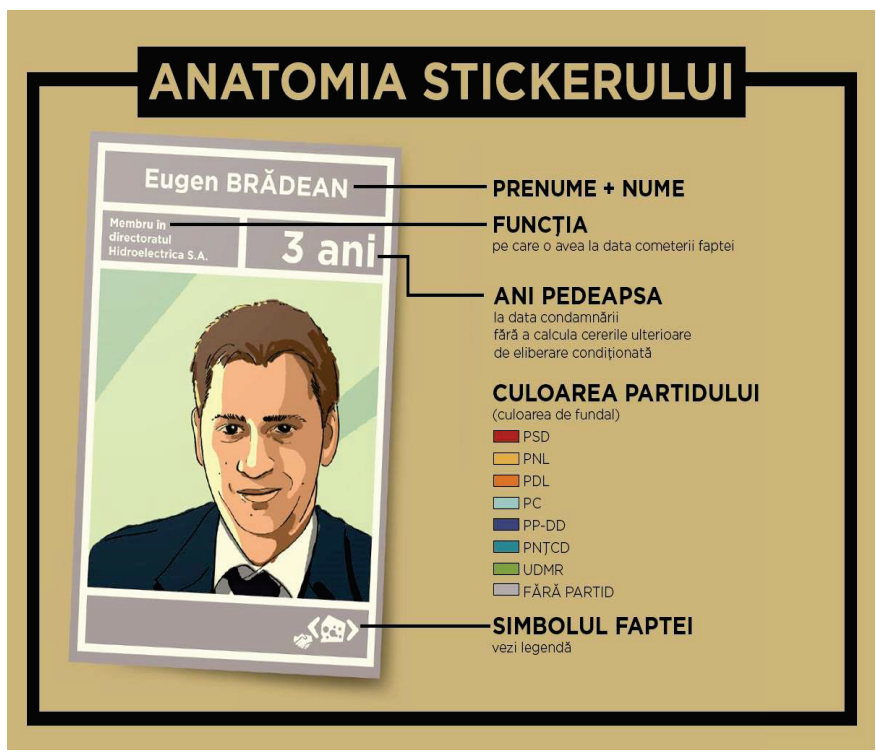

Source: Facebook Page of Mari Corupti.

Some visual representations of the project are worth discussing so as to understand the strategies used. In Figure 1, one can notice an example of one of these collectable cards, part of an initial 20-piece set. The card illustrates a graphic representation of a "great corrupt figure", the

\footnotetext{
${ }^{7}$ https://maricorupti.ro

${ }^{8}$ Direcția Națională Anticorupție (National Anticorruption Directorate).

${ }^{9}$ This kit was distributed with number 21 of this magazine, June 2015, https://www.dor.ro/ce-inseamna-sa-fii-abonatla-dor/
} 
office he/she held at the time of committing the crime, the initial duration of the sentence (without counting the later requests for probation), party affiliation and a small symbol representing the act of corruption. This set of cards is accompanied by a legend, where each act of corruption is ironically represented by a symbol, that together make up a small, illustrated dictionary of corruption. In the example above, the symbol stands for complicity in giving and receiving a bribe. Two shaking hands symbolize complicity, while the bribe is showed by a slice of cheese, a Romanian slang term for money.

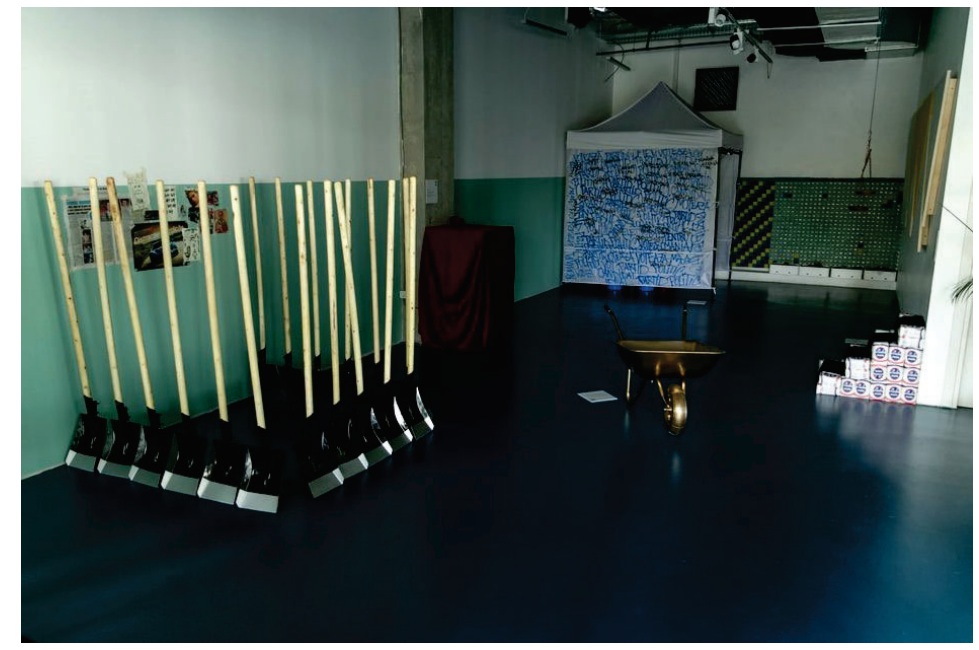

Source: https://www.libertatea.ro/stiri/galeria-trocului-electoral-expozitie-a-mitei-date-de-partide-in-campanii-2783136

The idea of this visual format of the database was to present the main project in a more humorous manner, and to infuse the anti-corruption theme with a pop-culture flavor (Pojoranu, 2015).

Galeria trocului electoral (The Gallery of electoral barter - Figure 2) was exhibited in a hub in Bucharest, showcasing many objects used as electoral bribes, part of another project of the NGO called Vot nu troc (Vote not barter). This project aimed to combat the phenomenon of electoral barter through a network of independent electoral observers for the presidential elections that took place on November 10 and 24, 2019. This project had two parts. "A gallery which exhibits many objects that constituted the raw material for electoral barter. The purpose was to show how easy it is to buy a vote and, therefore, how important it is to observe the elections" (VotNuTroc - 
Fii cu ochii pe vot, 2020). This gallery opened its doors on October 22 and closed on November 2 - taking place during the electoral campaign for the first round of the 2019 presidential elections.

Form the very beginning the visitor of the gallery was well prepared for the experience that he/she was about to have. A short note, displayed at the entrance, read:

"Vote = barter? No. But that's what the candidates think. We have identified hundreds of cases of electoral barter in the past 30 years. From lighters, to pens, slippers or boots, phones, drugs, food, prescription glasses, bedspread, pantyhose or even underwear and the list goes on. We have selected the most common ones; we have interpreted them as installation art, and we welcome you to the Gallery of electoral bribe!"

As the welcome note shows, this was a space that had the ambition to create a temporary anti-electoral corruption museum ${ }^{10}$ aiming to provoke social commitment. Therefore, this gallery was supplemented by the second part of this project that dealt with the actual electoral observation, through a network of observers. As this article limits its scope to visual representations of anticorruption practices, the analysis only takes into account the first part of the project.

\section{A new language to channel the anti-corruption project}

The work of Funky Citizens can be thought of as an example of artivism, although discursively, the members of this association don't describe themselves as artists. They collaborate though, with several visual artists that help them illustrate some of their ideas and reach out to their audience. Thus, artivism can, in this specific case, become an instrument that helps explain, analyze and most importantly show the universality of a certain type of human action.

For the Mari Corupti project, Funky Citizens collaborated with several illustrators that took care of the visual part of the project, to make it more attractive, more appealing to a nonexpert public and easier to remember. They also have an open ongoing call for future collaboration with possible interested graphic artists. Moreover, their exhibition makes use of artistic means of expression in two different ways. First of all, the NGO collaborates with artists for setting out the actual space of the gallery. Secondly, a gift shop was set up as part of the project, and "artists such

\footnotetext{
${ }^{10}$ Here you can find a virtual guide of the gallery: https://ocurus.com/tour/Mzg1MA==
} 
as Dan Perjovschi, Wanda Hutira, Diana Papuc, Victor Firan, George Popa donated reinterpreted objects of the electoral exchange as they were imagining it." (Oprea, 2019). This helps elucidate the relationship that is established in this case between activism and art. To a great degree, this NGO instrumentalizes artistic means because they facilitate, as Girma Negash writes, "the comprehension of political abstraction because of the vocabulary that is availed to us in the tools and modes we have borrowed from myth, symbols, and figures of speech" $(2004,197)$. Moreover, this association takes advantage of artistic means of creation and expression in the interest of mobilizing citizens.

"We started from a real tension: the electoral barter cannot be stopped by the average citizen, but we could encourage a type of valuable community and social behavior: participating as an observer at elections, something that would help a clean vote. I believe very much in the value of the small good: each one of us (realistically, if as many of us) would do a small good deed, then a bigger good deed would happen. Precisely of this type of thinking we wanted to talk about in our campaign for recruiting observers for Funky Citizens" (Chirițescu, 2019).

As the head of strategy for the campaign puts it, art can have a pragmatic role. It is used here as a means of raising awareness of the spread of the electoral barter as political behavior in the pursuit of social support for electoral observation. Even more, art is deployed as a device to provide financial aid. Commercializing the Big corrupt figures kit is, for one of the members of the association, a source of income, meant to ensure the financial independence of the association. It can also be, later on, reinvested in other anti-corruption projects (Pojoranu, 2015). The artworks sold in the gift shop of the gallery are intended to help raise money for ensuring support for the electoral observers during the election day.

If artivism is a new language, what types of ideas is it channeling and what other type of action it encourages? Funky Citizens is, as we argued, an example of anticorruption modernizing agent, therefore, the time has come to identify the main characteristic of its modernizing project.

Above all, it signals a change in attitude towards corruption. If compared to the normalizing and fatalistic approach, that marked, as we argue, the first post-communist decade in Romania, this new way of seeing the phenomenon is a less passive one. More precisely, this modernizing project involves action, with the long-term aim of social change, of making corruption an abnormal 
political behavior. In this sense, the Big Corrupt figures was conceived as an homage to the National Anticorruption Directorate, to show their support and help include one day this critique in the public grammar (Lemieux, 2018). There was a time in Romania, not so long ago, when one could have felt powerless facing the spread of this type of behavior among politicians. Nowadays, the activist world shows there are plenty of things that you can do, all you need is perseverance (Pojoranu, 2015).

No less interesting, this project describes corruption as a source of conflict that implies positioning. Thus, an ideal society is liberated from this burden, where unjust politicians and public figures are punished accordingly. Although positioning has a political ring attached, in this case, the anti-corruption fight transcends political parties and old ideologies. While openly assuming where they stand, for Funky Citizens it is very important to publicly emphasize their antipathy to any political affiliation. They have no political color, they are on the citizens' side, trying to leave behind a memorial of corruption, during the eternal transition from totalitarianism to democracy (Maricorupti - Despre, 2020). This reinforces our hypothesis that this new political cleavage that gravitates around the theme of corruption goes beyond the existing partisan affiliation or ideologies. In the constant challenge to understand this anti-corruption modernizing ideal, this fragment shows us the extent of what we have just identified as a preeminent feature.

"Why would someone collect corrupt figures?

Because you like the way they are drawn, because 'you're not on the bear's side', but on the anticorruption fighters' side, like all decent people are, so you're happy to see a 'Dan Voiculescu' card with '10 years' written on it. And also, because one day you'll have grandchildren, and you'll like to be able to show them this insectarium that displays all the country's 'pests"' (Pojoranu, 2015)

Last but not least, this anti-corruption program is an educational one. More precisely, this is consistent to the desire to contribute through alternative education means to the build-up of active citizenship, as mentioned at the beginning of this sub-section. Overall, education is a primordial objective of this NGO in all their projects. In the selected cases this rhymes with a desire to contribute to the articulation of a certain type of public memory. The examples previously quoted back up this statement. Besides this openly assumed pledge, imagining the present situation 
as an insectarium shows the desire to make sure that corrupt politicians will become a memory, yet an unforgettable one.

"We collect big corrupt figures to remember this historical moment because 5 years ago we weren't able to imagine that mister Adrian Năstase or mister George Copos will ever be convicted. They couldn't imagine it either and here they are today facing this uncomfortable reality." (Pojoranu, 2015)

This vocation is clearer in the case of the Gallery of the electoral barter, perceived since the beginning, both by the public and by the participants as an original type of museum. "Funky Citizens organized a 'museum' of the electoral bribe. So, it becomes history” (Bunea, 2019). This is a simple and concise statement that sums up another attempt of this organization to contribute to the writing of a history of corruption in Romania. Therefore, to this NGO, corruption is not a defining trait of the Romanian culture, but more likely a threat to democracy that needs to be acknowledged. Progress in this direction has been made, so their role is to keep track of the achievements while trying to convince more citizens to support of their modernizing ideal.

\section{Concluding remarks and future leads}

In conclusion, it might be worth restating the general argument of this article. In attempting to grasp the actions through which local Romanian actors contribute to the process of denormalization of corruption, this study argued that through a specific form of artivism, Funky Citizens is an example of modernizing agent in post-communist Romania. Having used a sociohistorical method to address this question, this research aimed to challenge the dominant approach on the matter. This translates into the desire to overcome the idea of corruption as a heavy Balkan heritage that explains the existence of a contestation movement only through external pressure. The argument put forward was that the specificity of the Romanian case could be grasped through the consideration of artivist means of expression of the actors that promote this modernizing project.

From a theoretical perspective, we argued that the example of this NGO showed the usefulness of the modernizing agent framework of analysis. More precisely, it allows the 
consideration of all types of Romanian political specificities, by overcoming more common analytical categories such as "right" and "left", "conservatives" and "progressives", and so on. This shows that the theme of corruption is a new source of conflict that produces new cleavages.

It is necessary to start by saying that this contribution focused, through the example of Funky Citizens, only on the anti-communist, later on anti-corruption modernity project (detailed in the second section of this article). The stretch of this endeavor is such that it showcased the actions of this type of actor, mobilized in the attempt to publicly denounce corruption as an “abnormal" political behavior, a shift in paradigm compared to the 90's and the early 2000. Therefore, the analysis of the local built-up of corruption as a public problem served as a basis for the description of the emergence and the dynamic of this modernizing ideal for the Romanian Society. On the basis of the presented evidence, what kinds of preliminary conclusions seem warranted regarding the operations through which Funky Citizens contribute to the denormalization of corruption?

In attempting to use artistic means of expression to deindividualize corruption in Romania, this NGO promotes the central idea of the existence of a systemic problem. Shortly, Funky Citizens proposes a central modernizing vector, that focuses on blaming the systemic corruption for social injustice and malfunctions. It creates thus, a space for collective reflection and debate through their projects, that have an educational vocation. Frist of all, this art based critical civic praxis puts forward the individual capacity of agency, in the relationship with the state's institutions but also on day to day basis. This goes hand in hand with the consolidation of certain type of public memory of corruption expressed via the idea of museum and gallery. Therefore, these initiatives not only have a growing importance when it comes to displaying the spread of this phenomenon, but they also keep track of all the work that has been done for the achievement of the modernizing ideal.

This type of artistic anti-corruption project is far from being unique. The anti-corruption museum in Bangkok, the unofficial Ukrainian museum of corruption, El Museo de la Corruptción in Paraguay are only a few well-known examples. Therefore, the present study does not claim the Romanian initiatives in this respect to be standalone. However, taking into account the artivist scene, the intention was to show the specificities of the endogenous articulation of this type of project, against forced generalizations.

Girma Negash argued that "intellectuals and artists everywhere assume a critical role in society because of their privileged position, and they possess the imagination and skills to create 
narratives, pictures, and images that construct and reconstruct political ideas and meaning" (2004, 191). Being guided by the same conviction, this study considered activist art a manifestation of this local color. Yet, this doesn't exclude the possibility of certain variety of anti-corruption movements. On the contrary, this transnational perspective could reveal certain similarities and even more specificities and provide material for some preliminary comparative reflections.

\section{Acknowledgement}

This research was supported by a grant of Ministry of Research and Innovation, CNCS UEFISCDI, project number PN-III-P1-1.1 - TE 2016 - 0346, within PNCDI III.

\section{References}

1. Aladro-Vico, E., Jivkova-Semova, D. and Bailey, O., 2018. Artivism: A new educative language for transformative social action. Comunicar, 26(57), pp. 09-18.

2. Blitstein, P. and Lemieux, C., 2018. Comment rouvrir la question de la modernité? Politix, 123(3), pp. 7-33.

3. Blitstein, P., 2018. L’opération typologique. Politix, 123(3), pp. 63-86.

4. Bratu R., 2018, Corruption, Informality and Entrepreneurship in Romania. Cham, Switzerland: Springer.

5. Bunea, I., 2019. GALERIE FOTO. Funky Citizens A Făcut Un Fel De „Muzeu” Al Mitei Electorale - „GaleriaTroculuiElectoral”. Ca SăDevinăIstorie. [online] Available at: $<$ https://www.paginademedia.ro/2019/10/vot-nu-troc-galerie\#comentarii $>$ [Accessed 9 January 2020].

6. Chiriac, M., 1997. Corupția nu mai e doar un concept. Revista 22, p. 2.

7. Chirițescu, Ș., 2019. Kubis Launched The Campaign "Vot, Nu Troc" - Available at: $<$ https://www.adhugger.net/2019/10/28/kubis-launched-the-campaign-vot-nu-troc/> [Accessed 10 January 2020].

8. Durkheim, E., Weber, F., Berthelot, J. and Mucchielli, L., 1960. Les Règles De La Méthode Sociologique. Paris, France: PUF.

9. Engles, J.I., Marton, S., Monier, F., 2017. Des politiques blancs comme neige. [online] Available at : https://laviedesidees.fr/Des-politiques-blancs-comme-neige.html [Accessed 14 April 2020]. 
10. Hein, M., 2015. The Fight Against Government Corruption in Romania: Irreversible Results or Sisyphean Challenge? Europe-Asia Studies, 67(5), pp. 747-776.

11. Hurezeanu, E., 1996. Little Big Man - despre corupție. Revista 22, p. 13.

12. Iancu, A. and Todorov, A., 2018. Reforms, Democratization And Anti-Corruption In Romania And Bulgaria. Bucureşti: Editura Universităţii din Bucureşti.

13. Iancu, A., 2018. Questioning Anticorruption in Postcommunist Contexts. Romanian MPs from Commitment to Contestation. Südosteuropa, 66(3), pp. 392-417.

14. Ionașcu, A., 2006. The evolution of parties supporting government forms of patronage in post-communist Romania. Sfera Politicii, pp. 123-124.

15. Kara, S. and Reestorff, C., 2015. Introduction: unruly documentary artivism. Studies in Documentary Film, 9(1), pp. 1-9.

16. Laclau, E., 2008. La Raison Populiste. Paris, France: Seuil.

17. Lemieux, C., 2018. La Sociologie Pragmatique. Paris, France: La Decouverte.

18. Lemieux, C., 2018. Paradoxe de la modernisation. Politix, 123(3), pp. 115-144.

19. Lippard, L., 1984. Trojan Horses: Activist Art And Power. [online] Available at: $<$ https://voidnetwork.gr/wp-content/uploads/2016/09/Trojan-Horses-Activist-Art-andPower-Lucy-Lippard.pdf> [Accessed 4 April 2020].

20. Michel, J., 2015. Mémoire Publique Et Mémoire Collective De L’Esclavage.[online] Espacestemps.net. Available at: <https://www.espacestemps.net/en/articles/memoirepublique-et-memoire-collective-de-lesclavage-2/> [Accessed 5 March 2020].

21. Mullin, A., 2003. Feminist Art and the Political Imagination. Hypatia, 18(4), pp. 189-213.

22. Mekdjian, S., 2018. Urban artivism and migrations. Disrupting spatial and political segregation of migrants in European cities. Cities, 77, pp. 39-48.

23. Negash, G., 2004. Art Invoked: A Mode of Understanding and Shaping the Political. International Political Science Review, 25(2), pp. 185-201.

24. Nossel, S., 2016. Introduction: On "Artivism", or Art's Utility in Activism. Social Research: An International Quarterly, 83(1), 103105. https://www.muse.jhu.edu/article/620871.

25. Oprea, A., 2019. Cinéma, mémoire et critique de la corruption dans la Roumanie et la Bulgarie postcommunistes. Etudes Balkaniques, 4, pp. 649-669 
26. Oprea, R., 2019. Kubis Launched The Campaign “Vot, Nu Troc” [online] AdHugger. Available at: <https://www.adhugger.net/2019/10/28/kubis-launched-the-campaign-votnu-troc/> [Accessed 14 April 2020].

27. Porojanu, C., 2015. Kitul Marilor Corupţi Şi Dicţionarul Explicativ Al Infracţiunilor. [online] Available at: <https:/www.digi24.ro/stiri/actualitate/politica/kitul-marilorcorupti-si-dictionarul-explicativ-al-infractiunilor-403810> [Accessed 15 April 2020].

28. Preda, C., 2005. Partide şi Alegeri în România Postcomunistă. Bucureşti, România: Nemira.

29. Radu, A., 2010. Reforma partidelor. Cazul PSD si PNL. Sfera Politicii, 145.

30. Rhoades M., 2012. LGBTQ Youth + Video Artivism: Arts-Based Critical Civic Praxis. Studies in Art Education, 53(4), pp. 317-329.

31. Rozin, P. (2006). Le concept de culturalisme dans les sciences anthropologiques : de Tylor à Lowie. Le Philosophoire, 27(2), 151-176. doi:10.3917/phoir.027.0151.

32. Sandoval C. and Latorre G., 2008. "Chicana/o Artivism: Judy Baca's Digital Work with Youth of Color". In Everett, A. (ed.) Learning Race and Ethnicity: Youth and Digital Media. Cambridge: MIT.

33. Sheikh, S., 2009. Positively Trojan Horses Revisited - Journal \#9 October 2009 - E-Flux. [online] E-flux.com. Available at: <https://www.e-flux.com/journal/09/61372/positivelytrojan-horses-revisited/> [Accessed 1 March 2020].

34. Văduva S. et al., 2016. From Corruption to Modernity. The Evolution of Romania's Entrepreneurship Culture, UK, London: Springer.

35. Votnutroc.ro, 2020. Votnutroc - Fii Cu Ochii Pe Vot. [online] Available at: $<$ https://votnutroc.ro> [Accessed 14 April 2020].

36. Zerilli, F., 2013. Corruption and anti-corruption local discourses and international practices in post-socialist Romania. Human Affairs, 23(2). 